\title{
T-cell nature of leukaemic cells in a case of Sézary's syndrome with 'null-cell' features
}

\author{
L. LAURIOLA, P. MUSIANi, A. CARBONE, M. BARTOLINI ${ }^{1}$, P. CIANCIULLI', \\ AND M. PIANTELLI
}

From the Department of Pathology, Università Cattolica, Rome, and ${ }^{1}$ Department of Haematology, Ospedale S. Eugenio, Rome, Italy

SUMMARY $\alpha$-naphthyl acetate esterase (ANAE) activity has been investigated in leukaemic cells from peripheral blood in a typical small-cell Sézary syndrome (SS) case in which cerebriform mononuclear cells failed to form E rosettes. The 'dot-like' ANAE positivity found in the majority of these neoplastic cells strongly supports a T-cell origin. In addition, a non-monocytic, non-B-cell nature of Sézary cells is indicated by the lack of Ia-like antigens. Finally, there is evidence of a distinct portion of Sézary cells simultaneously expressing ANAE activity and Fc IgM receptors.

Sézary's syndrome (SS) is a human lymphoproliferative disease in which malignant cells with T-cell characteristics are found in skin infiltrates as well as in peripheral blood (Edelson et al., 1974a; Preud'Homme and Seligmann, 1974; Zucker-Franklin et al., 1974). The T-cell nature of Sézary cells is supported by the capacity to form rosettes with sheep red blood cells (E rosettes). However, some typical SS cases have been reported in which the neoplastic cells failed to form $E$ rosettes (Wybran and Fudenberg, 1973; Edelson et al., 1974b; Braylan et al., 1975; Goldstone et al., 1976). In these cases the T-cell nature of the neoplastic cell proliferation remains putative. Therefore the search for other distinguishing T-cell markers could lead one to ascertain the origin of these undefined cells.

In addition to the capacity to form rosettes with sheep red blood cells, a distinctive, dense, localised, 'dot-like', non-specific acid $\alpha$-naphthyl acetate esterase (ANAE) positivity has been demonstrated in the vast majority of human T-cells (Ranki et al., 1976; Horwitz et al., 1977; Kulenkampff et al., 1977; Tötterman et al., 1977; Knowles et al., 1978; Ranki, 1978) as a distinguishing feature of thymusderived lymphocytes. Human $T$ lymphocytes have recently been shown to express receptors that bind the Fc portion of IgG $\left(\mathrm{T}_{G}\right)$ or IgM $\left(\mathrm{T}_{M}\right)$ (Dickler et al., 1974; Ferrarini et al., 1975; Moretta et al., 1975 ); up to $95 \%$ of the $T_{M}$ cells are esterasepositive and $90 \%$ of the $\mathrm{T}_{\mathrm{G}}$ cells are completely esterase-negative (Grossi et al., 1978).

Received for publication 22 February 1979
It was shown that, in acute lymphoblastic leukaemias with T-cell surface characteristics, ANAE positivity may be a further specific marker for thymus-derived lymphocytes (Kulenkampff et al., 1977; Knowles et al., 1978).

In the present study we investigated the ANAE activity in leukaemic cells from the peripheral blood of a case of SS in which typical cerebriform mononuclear cells failed to form $E$ rosettes but showed in very high proportion an ANAE 'dot-like' positive reaction. Moreover, in order to obtain more detailed information into the origin of these Sézary cells, we tried to find if Ia-like molecules were expressed by the leukaemic population. Ia-like molecules were recognised initially as alloantigens, primarily represented on B lymphocytes. Later, in addition to their presence on B cells and monocytes, they have been detected on leukaemic blasts in cases of acute lymphocytic leukaemia, acute myelogenous leukaemia, and chronic myelogenous leukaemia in blastic crisis (Fu et al., 1975; Schlossman et al., 1976; Winchester et al., 1975, 1976). On normal human T-cells, the presence of Ia-antigens has not been well documented.

\section{Case report}

A 55-year-old man was referred to this hospital because of a persistent peripheral blood lymphocytosis associated with exfoliative erythroderma and generalised adenopathy. The haemoglobin was 13.5 $\mathrm{g} / \mathrm{dl}$ and the white cell count $22 \times 10^{9} / 1$ with $33 \%$ neutrophils, $65 \%$ lymphocytes, and $2 \%$ monocytes. 
After separation of the mononuclear cells on FicollHypaque gradient, more than $89 \%$ of the cells under consideration showed the typical cerebriform nucleus when examined under the electron microscope. Bone marrow and lymph node biopsy showed infiltrating cells with the morphological features of atypical peripheral blood lymphocytes.

\section{Material and methods}

\section{CELL SEPARATION}

Peripheral blood mononuclear cells were isolated on Ficoll-Hypaque density gradient (Bøyum, 1968), and adherent cells were removed by incubation at $37^{\circ} \mathrm{C}$ for 60 minutes in plastic Petri dishes. Enumeration and separation of cells rosetting with neuraminidasetreated sheep erythrocytes $\left(E_{N}-R F C\right)$ were performed as previously reported (Piantelli et al., 1979).
SURFACE MARKER STUDIES

Surface immunoglobulin was investigated by the direct immunofluorescence test, as previously reported by us (Salsano et al., 1979).

Detection of lymphocytes with receptors for the Fc portion of IgG or IgM was performed as described in a previous paper (Lauriola et al., 1979).

The presence of Ia-like antigens on mononuclear cells was investigated by $\mathrm{Dr}$ Rosa Sorrentino, Laboratory of Cell Biology, CNR, Rome. An inhibition test was performed, using human purified radioiodinated Ia-molecules prepared from the RPMI 8057 cell line as antigen and a rabbit anti B-cell membrane heteroantiserum produced with membrane material of a B-cell type line 5329-1117 (Koyama et al., 1977; Tosi et al., 1978). Briefly, Renex-30 solubilised material from Sézary cells or chronic lymphatic leukaemia of B origin $\left(10 \times 10^{6}\right.$

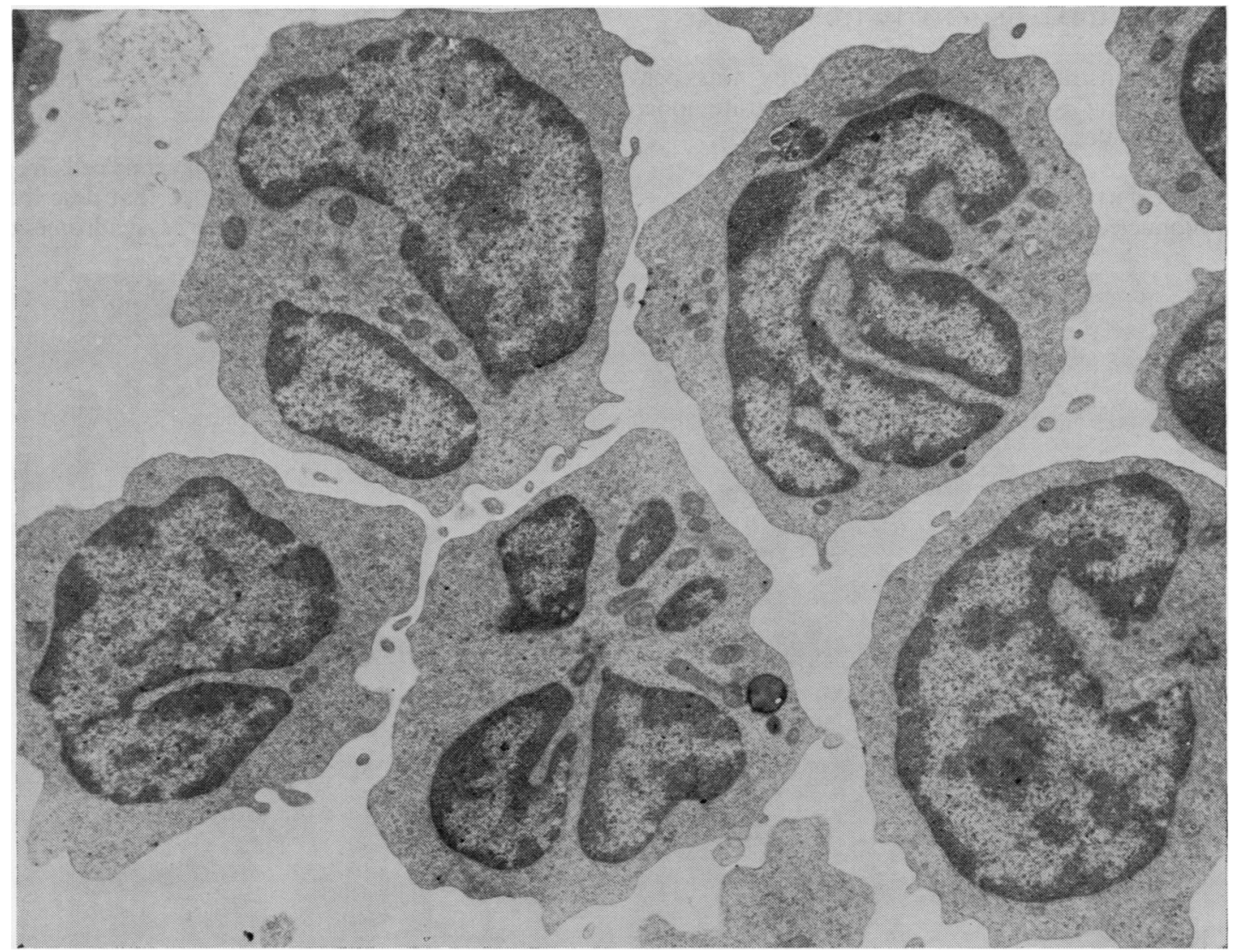

Fig. 1 Low-power survey electron photomicrographs of typical Sézary cells showing characteristic convoluted nuclei and large nucleoli. $(\times 6800)$. 
Table Comparative percentages of immunological and cytochemical markers in peripheral mononuclear cells* from Sézary syndrome patient and two normal subjects

\begin{tabular}{|c|c|c|c|c|c|c|}
\hline \multirow[t]{2}{*}{ Peripheral mononuclear cells } & \multicolumn{3}{|l|}{$R F C s$} & \multirow[t]{2}{*}{ Surface Ig } & \multicolumn{2}{|c|}{$A N A E$ activity } \\
\hline & $E_{N}$ & $E A \operatorname{Ig} M$ & $E A I g G$ & & Dot-like & Diffuse \\
\hline \multicolumn{7}{|l|}{ Sézary syndrome patient } \\
\hline Unfractionated & 7 & 35 & 12 & 4 & 88 & 1 \\
\hline E $_{\text {N-enriched }}$ & 94 & 61 & 16 & $<1$ & 72 & $<1$ \\
\hline $\mathbf{E}_{\mathrm{N}}$-depleted & $<1$ & 29 & 2 & 4 & 86 & $1 \cdot 5$ \\
\hline \multicolumn{7}{|l|}{ Normal subjects (A/B) } \\
\hline Unfractionated & $73 / 78$ & $39 / 34$ & $22 / 16$ & $9 \cdot 5 / 15$ & $54 / 61$ & $4 / 3$ \\
\hline $\mathbf{E}_{\mathrm{N}}$-enriched & $97 / 99$ & $59 / 64$ & $16 / 10$ & $1 /<1$ & $73 / 79$ & $<1 /<1$ \\
\hline
\end{tabular}

*Adherent cells depleted preparations.

cells/ $\mathrm{ml}$ in both cases) was incubated with the anti B-cell membrane heteroantiserum, followed by the addition of radioiodinated antigen; goat anti-rabbit immunoglobulin was then added and immunoprecipitate radioactivity was determined. The results were expressed as per cent inhibition of binding of radioiodinated Ia-antigens by rabbit antiserum.

\section{CYTOCHEMICAL DEMONSTRATION OF ANAE ACTIVITY}

The demonstration of esterase activity was performed using $a$-naphthyl acetate as substrate under conditions described by Mueller et al. (1975).

ULTRASTRUCTURAL STUDIES

Mononuclear cell preparations were fixed in $2.5 \%$ glutaraldehyde in $0.1 \mathrm{M}$ phosphate buffer $\mathrm{pH} 7.4$ and processed for electron microscopy.

\section{RESPONSE OF MONONUCLEAR CELLS}

TO PHYTOMITOGENS

Blast cell transformation after stimulation with Phytohaemagglutinin, Concanavalin A, and Pokeweed mitogen was performed as previously described (Lauriola et al., 1979).

\section{Results}

\section{ULTRASTRUCTURE}

The morphology (Fig. 1) of the leukaemic cells from peripheral blood appeared similar to that described in the small cell variant of Sézary's syndrome by

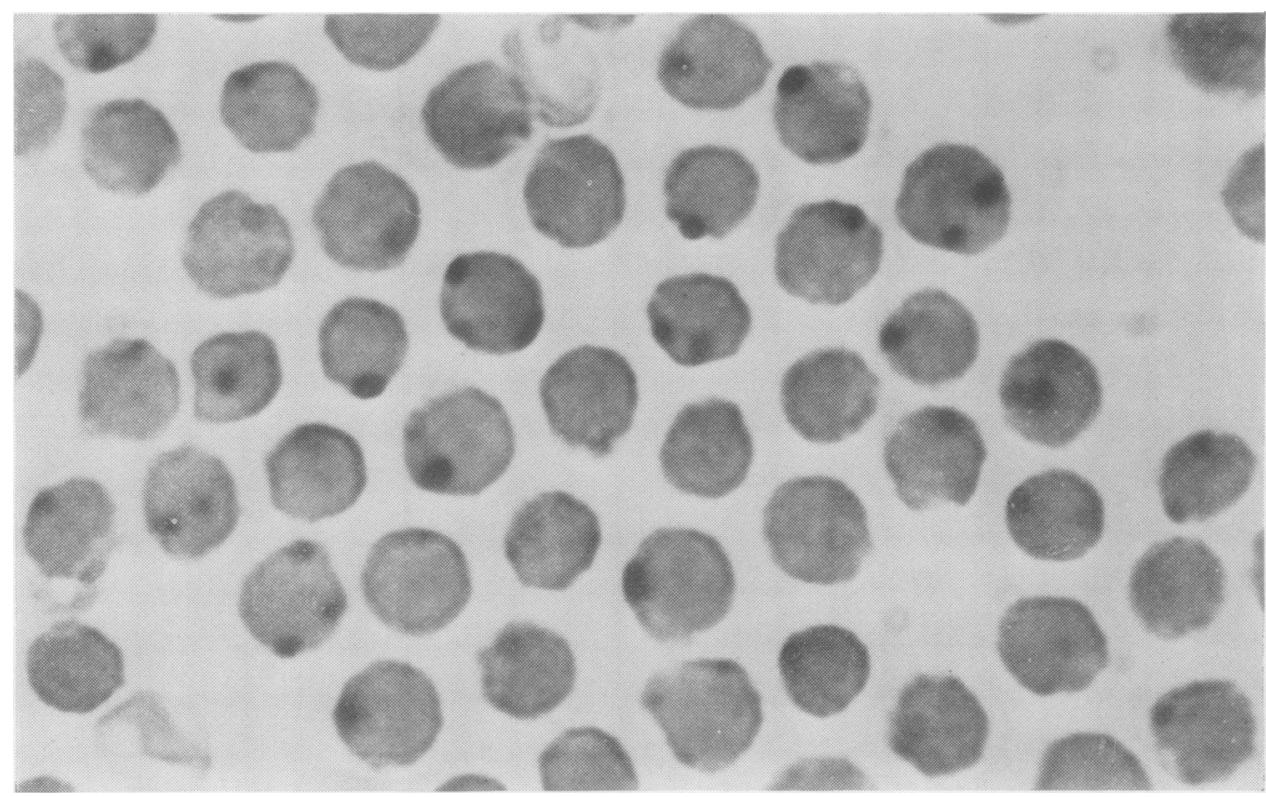

Fig. 2 Cytocentrifuge smear of Sézary cell enriched population. The majority of the cells display a typical 'dot-like' cytoplasmic reaction product adjacent to the cell membrane. $(\times 1000)$. 
several authors (Lutzner et al., 1973; Edelson et al., 1974b; Goldstone et al., 1976). The abnormal mononuclear cells showed an infolded nucleus with less prominent irregularity than the classic Sézary cell. Frequently, a well-developed nucleolus was observed. The nuclear/cytoplasmatic ratio was, in general, high.

\section{IMMUNOLOGICAL MARKERS}

The percentage of several surface markers in the peripheral blood mononuclear population, $E_{N}$ rosetting population $\left(E_{N}-R F C\right)$, as well as $E_{N}$ rosette forming cells depleted preparation $\left(E_{N}-R F C\right.$ depleted), from the leukaemic patient are shown in the Table. In the same table the values obtained in the peripheral blood mononuclear cells of two healthy donors are given.

The $E_{N}-R F C$ depleted preparation from a Sézary syndrome patient on ultrastructural examination showed the vast majority of cells with typical Sézary small cell features $(94 \%)$; on the other hand, the $E_{N}$ rosetting fraction revealed a typical lymphocytic population with rare, contaminating Sézary cells.

A $50 \%$ inhibition of binding between specific antiserum and radioiodinated Ia antigens was attained with $16 \mu$ l of chronic lymphatic leukaemia preparation but failed to be reached even with a 30-fold amount of $E_{N}-R F C$ depleted cell preparation from the Sézary syndrome patient.

\section{CYTOCHEMICAL INVESTIGATIONS}

The results of cytochemical investigations on the SS leukaemic population in toto and on the $\mathrm{E}_{\mathrm{N}}$ rosetting population, as well as in the $E_{N}-R F C$ depleted prepararion, are reported in the Table and compared with data from two normal subjects. The typical pattern of ANAE activity exhibited by the Sézary cell enriched population is shown (Fig. 2).

\section{RESPONSE TO PHYTOMITOGENS}

The peripheral blood SS mononuclear preparation depleted of $E_{N}-R F C$ failed to respond when cultured with phytomitogens (data not shown).

\section{Discussion}

The present study provides a more detailed insight into the characteristics of the neoplastic population in SS and supplies further criteria for the assessment of the true cellular origin when Sézary cells lack the E rosetting capacity.

In our SS case, the neoplastic population, which shared the morphological appearances of the small cell variant, failed to form $E$ rosettes. Only in one of several SS null-cell variant cases reported has the
$T$ nature of leukaemic cells been corroborated by the presence of human thymic lymphocyte antigenpositive cells (Edelson et al., 1974b).

'Dot-like' ANAE positivity of a distinctive lymphocyte population in normal human peripheral blood and lymphoid tissues correlates with an E rosette forming cell population. Moreover, an association between E marker positivity and ANAE 'dot-like' activity has been shown in leukaemic cells (Kulenkampff et al., 1977; Knowles et al., 1978). Thus, the demonstration of ANAE activity appears to be a useful T-cell marker and a reasonable alternative to E rosetting capacity. The 'dot-like' ANAE positivity that we have found in the vast majority of the peripheral blood Sézary cell enriched population ( $E_{N}-R F C$ and monocytic cells depleted) strongly supports a T-type origin.

The absence of $\mathrm{E}$ rosetting capacity in our SS case, as well as in a single childhood acute lymphoblastic leukaemia case reported by Kulenkampff $e t$ al. (1977), may be interpreted as an alteration in the maturative process leading to a dissociation in the normal expression of the two markers.

A non-monocytic, non-B cell origin of Sézary cells is further supported by the lack of Ia-like antigens. In fact, Ia-like antigens have generally been thought not to be expressed by normal or leukaemic T cells in man, although very recently Ia molecules have been demonstrated on a small population of normal peripheral $\mathrm{T}$ cells, on $\mathrm{T}$ cells grown in long-term cultures (Fu et al., 1978), and on $\mathrm{T}$ lymphocytes sensitised in a mixed leucocyte culture (Evans et al., 1978).

The finding that a portion of Sézary cell enriched population bear receptors for the Fc portion of IgM is consistent with the recent findings of Worman et al. (1978) and Gupta et al. (1978), although Sézary cells in these reported cases exhibited a very high percentage of E RFC. In the present study, as shown in the Table, the sum of ANAE 'dot-like' positive and Fc-IgM receptors bearing cell values exceeded $100 \%$, suggesting the presence of cells simultaneously expressing both markers.

Peripheral blood E rosetting cells from our SS patient were morphologically normal $\mathrm{T}$ lymphocytes; in addition, they expressed Fc-receptors for IgM and IgG in the same ratio as peripheral T cells from normal subjects.

In conclusion, our observation in a typical SS case shows that non $\mathrm{E}$ rosetting leukaemic cells may express other $T$ cell features and emphasises the usefulness of several techniques in order better to classify lymphoproliferative disorders.

We are grateful to $\mathrm{Mr}$ N. Maggiano and $\mathrm{Mr} \mathrm{P}$. Baldassarri for excellent technical assistance. This 
work was supported by a grant from the Consiglio Nazionale delle Ricerche (Progetto Finalizzato 'Controllo della Crescita Neoplastica').

\section{References}

Bøyum, A. (1968). Separation of leukocytes from blood and bone marrow. Scandinavian Journal of Clinical and Laboratory Investigation, 21, Supplement 97, 4.

Braylan, R., Variakojis, D., and Yachnin, S. (1975). The Sézary syndrome lymphoid cell: abnormal surface properties and mitogen responsiveness. British Journal of Haematology, 31, 553-564.

Dickler, H. B., Adkinson, N. F., Jr., and Terry, W. D. (1974). Evidence for individual human peripheral blood lymphocytes bearing both $\mathbf{B}$ and $\mathbf{T}$ cell markers. Nature, 247, 213-215.

Edelson, R. L., Kirkpatrick, C. H., Shevach, E. M., Schein, P. S., Smith, R. W., Green, I., and Lutzner, M. (1974a). Preferential cutaneous infiltration by neoplastic thymus-derived lymphocytes. Annals of Internal Medicine, 80, 685-692.

Edelson, R. L., Lutzner, M. A., Kirkpatrick, C. H., Shevach, E. M., and Green, I. (1974b). Morphologic and functional properties of the atypical $\mathrm{T}$ lymphocytes of the Sézary syndrome. Mayo Clinic Proceedings, 49, 558-566.

Evans, R. L., Faldetta, T. J., Humphreys, R. E., Pratt, D. M., Yunis, E. J., and Scholssman, S. F. (1978). Peripheral human $\mathrm{T}$ cells sensitized in mixed leukocyte culture synthesize and cxpress Ia-like antigens. Journal of Experimental Medicine, 148, 1440-1445.

Ferrarini, M., Moretta, L., Abrile, R., and Durante, M. L. (1975). Receptors for IgG molecules on human lymphocytes forming spontaneous rosettes with sheep red cells. European Journal of Immunology, 5, 70-72.

Fu, S. M., Chiorazzi, N., Wang, C. Y., Montazeri, G., Kunkel, H. G., Ko, H. S., and Gottlieb, A. B. (1978). Ia-bearing $\mathrm{T}$ lymphocytes in man. Their identification and role in the generation of allogeneic helper activity. Journal of Experimental Medicine, 148, 1423-1428.

Fu, S. M., Winchester, R. J., and Kunkel, H. G. (1975). The occurrence of the HL-B alloantigens on the cells of unclassified acute lymphoblastic leukemias. Journal of Experimental Medicine, 142, 1334-1338.

Goldstone, A. H., Cawley, J. C., Roberts, S. O., Leventine, A., and Barker, C. R. (1976). A case of small-cell Sézary's syndrome with null-cell features. Journal of Clinical Pathology, 29, 848-851.

Grossi, C. E., Webb, S. R., Zicca, A., Lydyard, P. M., Moretta, L., Mingari, M. C., and Cooper, M. D. (1978). Morphological and histochemical analyses of two human $\mathrm{T}$-cell subpopulations bearing receptors for IgM or IgG. Journal of Experimental Medicine, 147, 1405-1417.

Gupta, S., Safai, B., and Good, R. A. (1978). Subpopulations of human T lymphocytes. IV. Quantitation and distribution in patients with mycosis fungoides and Sézary syndrome. Cellular Immunology, 39, 18-26.

Horwitz, D. A., Allison, A. C., Ward, P., and Kight, N. (1977). Identification of human mononuclear leucocyte populations by esterase staining. Clinical and Experimental Immunology, 30, 289-298.

Knowles, D. M., II, Hoffman, T., Ferrarini, M., and Kunkel, H. G. (1978). The demonstration of acid $\alpha$-naphthyl acetate esterase activity in human lymphocytes: usefulness as a T-cell marker. Cellular Immunology, 35, 112-123.

Koyama, K., Nakamuro, K., Tanigaki, N., and Pressman, D. (1977). Alloantigens of human lymphoid cell lines; "human Ia-like antigens" alloantigenic activity and cell line, organ and tissue distribution as determined by radioimmunoassy. Immunology, 33, 217-230.

Kulenkampff, J., Janossy, G., and Greaves, M. F. (1977). Acid esterase in human lymphoid cells and leukaemic blasts: a marker for T lymphocytes. British Journal of Haematology, 36, 231-240.

Lauriola, L., Piantelli, M., Carbone, A., Dina, M. A., Scoppetta, C., and Musiani, P. (1979). Subpopulations of lymphocytes in human thymomas. Clinical and Experimental Immunology. (In press.)

Lutzner, M. A., Emerit, I., Durepaire, R., Flandrin, G., Grupper, C., and Prunieras, M. (1973). Cytogenetic cytophotometric, and ultrastructural study of large cerebriform cells of the Sézary syndrome and description of a small-cell variant. Journal of the National Cancer Institute, 50, 1145-1162.

Moretta, L., Ferrarini, M., Durante, M. L., and Mingari, M. C. (1975). Expression of a receptor for IgM by human T cells in vitro. European Journal of Immunology, 5, 565-569.

Mueller, J., Brun Del Re, G., Buerki, H., Keller, H. U., Hess, M. W., and Cottier, H. (1975). Nonspecific acid esterase activity: a criterion for differentiation of $\mathrm{T}$ and B lymphocytes in mouse lymph nodes. European Journal of Immunology, 5, 270-274.

Piantelli, M., Lauriola, L., Carbone, A., Evoli, A., Tonali, P., and Musiani, P. (1979). Subpopulations of $\mathrm{T}$ lymphocytes in myasthenia gravis patients. Clinical and Experimental Immunology. 36, 85-89.

Preud'Homme, J. L., and Seligmann, M. (1974). Surface immunoglobulins on human lymphoid cells. Progress in Clinical Immunology, 2, 121-174.

Ranki, A. (1978). Nonspecific esterase activity in human lymphocytes. Histochemical characterization and distribution among major lymphocyte subclasses. Clinical Immunology and Immunopathology, 10, 47-58.

Ranki, A., Tötterman, T. H., and Häyry, P. (1976). Identification of resting human $\mathrm{T}$ and $\mathrm{B}$ lymphocytes by acid $\alpha$-naphthyl acetate esterase staining combined with rosette formation with staphylococcus aureus strain Cowan 1. Scandinavian Journal of Immunology, 5, 1129-1138.

Salsano, F., Pisarri-Salsano, S., Ciancarelli, M. P., Piantelli, M., Lauriola, L., and Musiani, P. (1979). Structural and functional characteristics of hairy cells. Acta Haematologica, 61, 184-193.

Schlossman, S. F., Chess, L., Humphreys, R. E., and Strominger, J. L. (1976). Distribution of Ia-like molecules on the surface of normal and leukemic human cells. Proceedings of the National Academy of Sciences of the United States of America, 73, 1288-1292. 
Tosi, R., Tanigaki, N., Centis, D., Ferrara, G. B., and Pressman, D. (1978). Immunological dissection of human Ia molecules. Journal of Experimental Medicine, 148, 1592-1611.

Tötterman, T. H., Ranki, A., and Häyry, P. (1977). Expression of the acid $\alpha$-naphthyl acetate esterase marker by activated and secondary $\mathrm{T}$ lymphocytes in man. Scandinavian Journal of Immunology, 6, 305-310.

Winchester, R. J., Fu, S. M., Wernet, P., Kunkel, H. G., Dupont, B., and Jersild, C. (1975). Recognition by pregnancy serums of non-HL-A alloantigens selectively expressed on B lymphocytes. Journal of Experimental Medicine, 141, 924-929.

Winchester, R. J., Wang, C. Y., Halper, J., and Hoffman, T. (1976). Studies with B-cell allo- and hetero-antisera: parallel reactivity and special properties. Scandinavian Journal of Immunology, 5, 745-757.

Worman, C. P., Burns, G. F., and Barker, C. R. (1978).
Evidence for the presence of a receptor for IgM on the pathological cells of Sézary's syndrome. Clinical and Experimental Immunology, 31, 391-396.

Wybran, J., and Fudenberg, H. H. (1973). Thymusderived rosette-forming cells in various human disease states: cancer, lymphoma, bacterial and viral infections, and other diseases. Journal of Clinical Investigation, 52, 1026-1032.

Zucker-Franklin, D., Melton, J. W., and Quagliata, F. (1974). Ultrastructural, immunologic, and functional studies on Sézary cells: a neoplastic variant of thymusderived (T) lymphocytes. Proceedings of the National Academy of Sciences of the United States of America, 71, 1877-1881.

Requests for reprints to: Dr L. Lauriola, Università Cattolica del Sacro Cuore, Istituto di Anatomia Patologica, Via della Pineta Sacchetti 644, 00168 Rome, Italy. 